\title{
Eksistensi Hukum Adat dalam Peraturan Daerah Studi Kasus Pemerintah Kota Sungai Penuh
}

\author{
Hainadri \\ ${ }^{1}$ Program Studi Hukum Ekonomi Syariah, Institut Agama Islam Negeri (LAIN) Kerinci \\ e-mail: hainadri.1981@gmail.com
}

\begin{abstract}
ABSTRAK. Masyarakat Kota Sungai Penuh memiliki tradisi yang beraneka ragam yang terdiri dari bermacam suku atau etnis. Kota Sungai Penuh memiliki 10 persekutuan Masyarakat adat yang masing-masing memiliki lembaga adat tersendiri. Namun secara umum Kota Sungai Penuh masih mengakui dan menganut hukum adat Kerinci sebagaimana sebelum daerah tersebut dimekarkan. Tujuan penelitian ini adalah memberikan informasi aktual tentang kondisi hukum adat yang ada di wilayah pemerintahan Kota Sungai Penuh. Kota Sungai Penuh sejak diresmikan menjadi daerah otonom baru sebagai hasil dari pemekaran Kabupaten Kerinci sejak tahun 2010 telah menghasilkan 124 (seratus dua puluh empat) peraturan daerah yang 44 (empat puluh empat) diantaranya sudah tidak berlaku lagi. Jadi ada 80 (delapan puluh) peraturan daerah yang masih berlaku sampai saat ini. Meskipun didefinisikan sebagai hukum yang tidak tertulis, keberadaan hukum adat sebagai salah satu sistem pemerintahan di daerah secara yuridis formal mendapat landasan yang kuat. Namun di Kota Sungai Penuh belum ada satupun Peraturan daerah yang mengatur tentang Hukum adat dan tidak satu pasalpun yang mengatur perihal hukum adat.
\end{abstract}

Kata kunci: eksistensi, hukum adat, peraturan daerah.

\section{PENDAHULUAN}

Sebelum dimekarkan menjadi kota tersendiri, Sungai Penuh merupakan ibu kota administratif dari Kabupaten Kerinci di Provinsi Jambi. Kabupaten Kerinci merupakan salah satu Kabupaten dengan jumlah penduduk yang relatif besar dibandingkan dengan Kabupaten lain di Provinsi Jambi. Kabupaten Kerinci memiliki luas $4200 \mathrm{~km}$ dan tediri dari 11 (sebelas) kecamatan yaitu : Kecamatan Gunung Raya, Kecamatan Batang Merangin, Kecamatan Danau Kerinci, Kecamatan Keliling Danau, Kecamatan Sungai Penuh, Kecamatan Hamparan Rawang, Kecamatan Sitinjau Laut, Kecamatan Air Hangat, Kecamatan Air Hangat Timur, Kecamatan Gunung Kerinci dan Kecamatan Kayu Aro.

Pemerintah Indonesia kemudian membagi Kabupaten Kerinci menjadi dua administrasi yaitu Kabupaten Kerinci (yang terdiri dari 12 kecamatan) dan Kota Sungai Penuh (yang terdiri dari 5 kecamatan). Pemekaran wilayah ini diresmikan oleh Menteri Dalam Negeri Indonesia dan disahkan dengan Undang-Undang Nomor 25 Tahun 2008 pada tanggal 21 Juli 2008. Pemekaran daerah ini merupakan implementasi dari kebijakan otonomi daerah.

Menurut Agustino (2011, hal. 69), konsep otonomi daerah membuat Pemerintah Daerah memiliki kewenangan yang luar biasa untuk merencanakan, merumuskan, 
melaksanakan, serta mengevaluasi kebijakan-kebijakan yang sesuai dengan keperluan dan tuntutan masyarakat setempat. Kewenangan tersebut merupakan tantangan tersendiri bagi Pemerintah Daerah Kota Sungai Penuh karena kondisi masyarakat Kota Sungai Penuh yang heterogen.

Menurut Jauhari (2012, hal 37), masyarakat Kota Sungai Penuh memiliki tradisi yang beraneka ragam yang terdiri dari bermacam suku atau etnis seperti: suku Melayu, suku Anak Dalam (suku Kubu), suku Banjau, suku Orang Batin dan suku Melayu Kerinci. Masing-masing suku tersebut memiliki pola hidup, pranata masyarakat, sistem tingkah laku dan hukum adat yang berbeda-beda. Namun secara umum Kota Sungai Penuh masih mengakui dan menganut hukum adat Kerinci sebagaimana sebelum daerah tersebut dimekarkan. Hal ini dapat dilihat dari keberadaan organisasi adat di Kota Sungai Penuh dan berbagai pelaksanaan kegiatan masyarakat yang mengacu kepada hukum adat.

Dalam buku Thontowi (2013, hlm. 21-36) Para ahli hukum adat sepakat bahwa dalam hukum adat mengandung unsur-unsur keagamaan, dan magis (magic religious), keajegan (constant), tunai (concrete) dan luwes (flexible). Hukum adat menurut Ter Haar Bzn dalam buku Hadikusuma (1992, hlm. 14) adalah keseluruhan aturan yang menjelma dari keputusan-keputusan para fungsionaris hukum (dalam arti luas) yang memiliki kewibawaan serta pengaruh dan yang dalam pelaksanaannya berlaku serta merta dan ditaati dengan sepenuh hati. Soepomo (1952, hlm. 30) berpendapat bahwa hukum adat adalah sinonim dari hukum yang tidak tertulis di dalam peraturan legislatif, hukum yang hidup sebagai konvensi di badan-badan hukum negara (parlemen, dewan propinsi, dan sebagainya), hukum yang hidup sebagai peraturan kebiasaan yang dipertahankan di dalam pergaulan, baik di kota maupun di desa-desa.

Meskipun didefinisikan sebagai hukum yang tidak tertulis, keberadaan hukum adat sebagai salah satu sistem pemerintahan di daerah secara yuridis formal mendapat landasan yang kuat. Eksistensi masyarakat adat di Indonesia diakui secara konstitusional sebagaimana diatur dalam UUD 1945 Amandemen ke-4 Pasal 18B ayat (2): "Negara mengakui dan menghormati kesatuan-kesatuan masyarakat adat beserta hak-hak tradisionalnya sepanjang masih hidup dan sesuai dengan perkembangan masyarakat dan prinsip Negara Kesatuan Republik Indonesia yang diatur dalam undang-undang”. UUD 1945 juga mengakui Hak Menguasai Negara, diangkat dari Hak Ulayat, Hak Pertuanan yang secara tradisional diakui dalam hukum adat. Masyarakat adat juga dilindungi dalam Undang-Undang Nomor 39 Tahun 1999 tentang Hak Asasi Manusia sebagaimana diatur dalam Pasal 6 ayat (1) dan ayat (2) yang menentukan: "Dalam rangka penegakan Hak Asasi Manusia perbedaan dan kebutuhan, dalam masyarakat hukum adat harus diperhatikan dan dilindungi oleh hukum, masyarakat, dan pemerintah."

Landasan yuridis formal tersebut memang telah mampu menegaskan eksistensi masyarakat adat di Indonesia namun belum mampu mengakomodasi hukum adat yang hidup di tengah masyarakat Indonesia. Latar belakang adat yang berbeda sesuai dengan wilayah adatnya masing-masing, hal ini menjadi penyebab adanya perbedaan hukum adat antara satu daerah dengan daerah yang lain. Selain itu faktor agama juga ikut mempengaruhi perbedaan ini. Untuk itu tataran hukum yang tepat untuk menjangkau dan mengakomodasi hukum adat di setiap daerah adalah dalam bentuk peraturan daerah.

Sebagai wilayah yang belum lama mengalami pemekaran, tidak dapat dipungkiri bahwa Kota Sungai Penuh masih dalam tahap penyempurnaan, baik dari sisi peraturan 
maupun pelaksanaan pemerintahan. Perlu adanya koordinasi antara berbagai pihak, khususnya antara Pemerintah Kota Sungai Penuh dengan masyarakat adat yang notabene telah lebih dulu hadir di tengah masyarakat Kota Sungai Penuh dan memiliki hukum adat tersendiri. Koordinasi tersebut terutama dalam hal pembentukan Peraturan Daerah yang tentu saja mengatur segala aspek kehidupan masyarakat Kota Sungai Penuh yang juga merupakan bagian dari masyarakat adat tersendiri. Inilah yang menjadi alasan penulis melakukan penelitian ini dengan tema, "Eksistensi Hukum Adat dalam Peraturan Daerah Kota Sungai Penuh".

\section{METODOLOGI}

Spesifikasi penelitian.

Metode penelitian yang digunakan dalam penelitian ini adalah metode deskriptif analitis. Menurut Sunggono (2010, hal. 37-38) “ Penelitian deskriptif analisa data tidak keluar dari lingkup sample. Bersifat deduktif, berdasarkan teori atau konsep yang bersifat umum diaplikasikan untuk menjelaskan tentang seperangkat data, atau menunjukkan komparasi atau hubungan seperangkat data dengan seperangkat data yang lain “.

\section{Pendekatan.}

Pendekatan yang dilakukan dalam penelitian ini adalah Penelitian hukum Sosiologis atau menurut Soetandyo Wignjosoebroto penelitian non doktrinal yaitu penelitian berupa studistudi empiris untuk menemukan teori-teori mengenai proses terjadinya dan mengenai proses bekerjanya hukum di dalam masyarakat (Socio Legal Research).

Data

Data adalah berasal dari data primer dan data sekunder sebagai berikut:

1. Data Primer diperoleh dari Tokoh-tokoh Adat di wilayah Kota Sungai Penuh, Anggota Dewan Perwakilan Rakyat Daerah Kota Sungai Penuh, Kepala Bagian Hukum dan Perundang-Undangan Sekretariat Daerah Kota Sungai Penuh, dan Kepala Bagian Pemerintahan Desa Sekretariat Daerah Kota Sungai Penuh.

2. Data Sekunder diperoleh dari data proses pemilihan Kepala Desa, laporan penelitian, buku-buku, kajian, referensi hukum, serta data lain yang relevan dengan objek penelitian.

\section{Teknik Pengumpulan data}

Pengumpulan data dilakukan dengan menggunakan dua teknik, yang diharapkan dapat menghasilkan data yang memenuhi syarat, lengkap dan relevan. Teknik pengumpulan data yang digunakan dalam penelitian ini diantaranya wawancara dan dokumentasi.

\section{Teknik analisis data}

Dalam penelitian ini, analisis data yang digunakan melalui pendekatan kualitatif. Menurut Irawan, Prasetya, (2004, hal. 99) "analisis data kualitatif adalah analisis yang dilakukan terhadap data non-angka seperti hasil wawancara, atau catatan laporan bacaan dari bukubuku, artikel, dan juga termasuk non tulisan seperti foto, gambar, atau film". Jadi dalam hal 
ini penulis mengembangkan analisis dari data yang sebenarnya tanpa mengubah data sebenarnya ke dalam bentuk apapun atau merekayasa data yang sebenarnya sudah ada.

\section{TEMUAN DAN PEMBAHASAN}

\section{Eksistensi Hukum Adat dalam Peraturan Daerah Kota Sungai Penuh}

Hukum adat sebagai hukum non statutoir, sesuai dengan sifatnya akan secara terus menerus tumbuh dan berkembang di masyarakat. Sebagai hukum tradisional dan asli hukum Indonesia, hukum adat digolongkan sebagai hukum yang primitif, sehingga tidak jarang banyak pihak yang meragukan eksistensi dan pendayagunaannya pada era modern seperti saat ini. Pihak yang meragukan tersebut menyatakan bahwa hukum adat adalah hukum yang tidak tertulis, sehingga jika dibandingkan dengan hukum yang tertulis, hukum adat dinilai tidak dapat memberikan jaminan kepastian hukum. Alasan lainnya adalah karena pada era unifikasi hukum, sangatlah sulit memadukan atau memilih hukum adat yang akan dijadikan patokan. Hal ini berdasarkan fakta bahwa hukum adat di tiap daerah di Indonesia memiliki perbedaan.

Sedangkan pihak yang lain, masih mengakui eksistensi pentingnya peran hukum adat pada era modern ini, mengingat bahwa tidak selamanya hukum tertulis yang berupa perundangundangan, dapat selalu mengikuti perkembangan masyarakat. Ketika terjadi kesenjangan seperti itu, maka peran hukum adat akan sangat penting, dengan mengacu pada sifat hukum adat yang bersifat dinamis. Peran penting lainnya, hukum adat sebagai hukum yang lahir, tumbuh dan berkembang di masyarakat, adalah sebagai sumber utama dari penyusunan dan perumusan aturan perundangundangan.

Kota Sungai Penuh sejak diresmikan menjadi daerah otonom baru sebagai hasil dari pemekaran Kabupaten Kerinci sejak tahun 2010 telah menghasilkan 124 (seratus dua puluh empat) Peraturan Daerah yang 44 (empat puluh empat) diantaranya sudah tidak berlaku lagi. Jadi ada 80 (delapan puluh) Peraturan Daerah yang masih berlaku sampai saat ini.

Berdasarkan hasil wawancara dengan Kabag hukum setda Kota Sungai Penuh tidak ada Peraturan daerah Kota Sungai Penuh yang mengatur tentang Hukum adat. Hal ini dibenarkan oleh Ketua DPRD Kota Sungai Penuh bahkan beliau menyatakan tidak satu pasalpun yang mengatur perihal hukum adat. Namun untuk tahun 2019 sudah ada rancangan peraturan daerah mengenai hukum adat dan hal ini dibenarkan oleh Bagian Hukum dan Persidangan Sekretaris DPRD Kota Sungai Penuh bahwa peraturan daerah tentang hukum adat sudah terdaftar dalam rencana pembahasan peraturan darah kota sungai penuh tahun 2019 tetapi draf rancangannya belum ada. Hal ini disebabkan masih dalam tahap pembahasan dan perancangan dalam forum adat Kota Sungai penuh

\section{KESIMPULAN}

Eksistensi hukum adat di Kota Sungai Penuh tidak begitu terlihat karena tidak begitu berperan dalam mengatur tingkah laku masyarakat baik itu dalam persekutuan adatnya masing-masing ataupun dalam masyarakat Pemerintah Kota Sungai Penuh dalam bentuk Peraturan daerah yang mengatur tentang Hukum adat. bahkan dalam Peraturan Daerah tidak satu pasalpun yang mengatur perihal hukum adat. Namun untuk tahun 2019 sudah 
menjadi rancangan pembahasan peraturan daerah mengenai hukum adat Kota Sungai Penuh

\section{REFERENSI}

Abdul Latief, Hukum dan Peraturan Kebijaksanaan (Beleidsregel) pada Pemerintahan Daerah, UII Press, Yogyakarta, 2005.

Ade Saptomo, Hukum dan Kearifan Lokal, Grasindo, Jakarta, 2010.Agustino, Leo, 2011. Sisi Gelap Otonomi Daerah: Sisi Gelap Desentralisasi di Indonesia Berbanding Era Sentralisasi, Bandung: Widya Padjadjaran.

Amrullah Ahmad, Islam Dalam Sistem Hukum Nasional, Gema Insani, Jakarta, 1996.

Arikunto dan Suharsimi, 2002, Prosedur Penelitian Suatu Pendekatan Praktek, Rineka Cipta, Jakarta.

Bagir Manan, Hubungan antara Pusat dan Daerah Menurut UUD 1945, Sinar Harapan, Jakarta, 1994.

Budi Susanto, S.J, Ingatan Hikmat Indonesia Masa Kini, Hikmat Masa Lalu Rakyat, Kanisius, Yogyakarta, 2005.

Jauhari, Budhi Vrihaspathi dan Eka Putra, 2012. Senarai Sejarah Kebudayaan Suku Kerinci, Jambi: Bina Potensia Aditya Mahatva Yodha Kota Sungai Penuh dan Kabupaten Kerinci Provinsi Jambi.

Hadikusuma, H. Hilman, 1992. Pengantar Ilmu bukum Adat Indonesia, Bandung: Mandar Maju.

Irawan, Prasetya, 2004, Logika dan Prosedur Penelitian (cetakan keenam), STIA-LAN, Jakarta.

Khairul Muluk, Desentralisasi Teori, Cakupan dan Elemen, http://www.publik.brawijaya.ac.id

Mahendra Putra Kurnia, dkk. Pedoman Naskah Akademik Perda, Partisipatif, yogyakarta: Kreasi Total Media

Manan, Bagir , 2002. Menyongsong Fajar Otonomi Daerah,Yogyakarta: PSH FH UII.

Maria Farida Indrati. S, Ilmu Perundang-undangan; Dasar-dasar dan Pembentukannya, Kanisius, Yogyakarta, 2007.

Marzuki Wahid dan Rumadi, Fiqh Madzhab Negara, LKiS, Yogyakarta, 2001.

Moh. Nazir, 2003, Metode Penelitian, Ghalia Indonesia, Jakarta.

Ni'matul Huda, Otonomi Daerab; Filosofi, Sejarah Perkembangan dan Problematika, Pustaka Pelajar, Yogyakarta, 2005. 
Ratno Lukito, Tradisi Hukum Indonesia, Jakarta, IMR Press, 2012.

R. Soepomo, 1952. Kedudukan Hukum Adat di Kemudian Hari, Jakarta: Pustaka Rakyat.

Soenobo Wirjosoegito, Proses \& Perencanaan Peraturan Perundangan, Ghalia Indonesia, Jakarta, 2004.

Suharjono, Muhammad, 2014, Pembentukan Peraturan Daerah yang Responsif dalam Mendukung Otonomi Daerah, Jurnal Ilmu Hukum No. 19 Vol. 10, Februari.

Sunggono, Bambang, 2010, Metodelogi Penelitian Hukum, PT Raja Grafindo Persada, Jakarta.

Thontowi, Jawahir, Perlindungan dan Pengakuan Masyarakat Adat dan Tantangannya dalam Hukum Indonesia, Jurnal Hukum Ius Quia Iustum No.1 Vol. 20, Januari 2013.

Victor M. Situmorang, Hukum Administrasi Pemerintaban di Daerah, Sinar Grafika, Jakarta, 1994. 